\title{
ANALYZING THE EFFECT OF INDIAN OCEAN DIPOLE PHENOMENON TO THE ANOMALIES DISTRIBUTION OF SEA SURFACE TEMPERATURE IN WEST SUMATERA
}

\author{
Nabila Afifah Azuga ${ }^{*}$, Musrifin Galib $^{2}$, Elizal $^{2}$ \\ ${ }^{1}$ Student of the Faculty of Fisheries and Marine Universitas Riau, Pekanbaru \\ ${ }^{2}$ Lecturer at the Faculty of Fisheries and Marine Universitas Riau, Pekanbaru \\ *nabilaafifahazg@gmail.com
}

\begin{abstract}
The waters of West Sumatera that face directly into Indian Ocean is strongly influenced by Indian Ocean Dipole (IOD) phenomenon which caused an anomaly of sea surface temperature (SST) and affect rainfall intensity in the West Sumatera Province. This research was aimed to know the effect of IOD on the distribution and anomaly of SST and rainfall intensity in West Sumatera. Data processing methods in this research is using statistical and descriptive. The data used in this research are NOAA OI-SST, Dipole Mode Index (DMI), and rainfall data from BKMG. The results showed that IOD positive occured in October 2018 and the IOD negative occured in July 2016. During the positive IOD, SST distribution values were $28{ }^{\circ} \mathrm{C}-28,8{ }^{\circ} \mathrm{C}$ and SST anomaly values were $-1,2$ to $-0,4$, in the negative phase the distribution of SST values were $29,8{ }^{\circ} \mathrm{C}-30,35^{\circ} \mathrm{C}$ and the SST anomaly values were 0,15 to 0,7 . The rainfall intensity during positive IOD phase is $157 \mathrm{~mm} / \mathrm{month}$ and during negative IOD phase is $525 \mathrm{~mm} /$ month.
\end{abstract}

Keywords: IOD, Sea Surface Temperature, Rainfall Intensity, West Sumatera Waters

\section{PENDAHULUAN}

Letak Indonesia secara geografis berada di antara dua benua yakni Asia dan Australia dan juga berada di antara dua samudera yaitu Pasifik dan Hindia. Para ahli berpendapat bahwa Samudera Hindia mempunyai peran yang sangat penting dalam mengendalikan iklim dunia, salah satunya di wilayah Indonesia bagian barat Sumatera yang di dalamnya mencakup Perairan Sumatera Barat. Perairan ini berada tepat di bawah garis ekuator dan berhadapan langsung dengan Samudera Hindia, sehingga sangat dipengaruhi oleh fenomena Indian Ocean Dipole (IOD) yang mengendalikan fluktuasi suhu permukaan laut (SPL).

IOD diidentifikasi sebagai salah satu mode utama variabilitas dalam iklim tropis
(Sahu et al., 2012). Kejadian IOD direpresentasikan dengan satu indeks yang diberi nama Dipole Mode Index (DMI), yaitu perbedaan SPL (anomali) di bagian barat Samudera Hindia $\left(50^{\circ}-70^{\circ} \mathrm{BT}, 10^{\circ}\right.$ LS - $\left.10^{\circ} \mathrm{LU}\right)$ dan SPL di bagian timur Samudera Hindia $\left(90^{\circ}-110^{\circ}, 10^{\circ} \mathrm{LS}\right.$ ekuator) (Kailaku, 2009).

Anomali SPL pada fase positif IOD ditandai dengan SPL dingin di perairan timur Samudera Hindia dan hangat di perairan barat Samudera Hindia. Sebaliknya, pada saat fase negatif IOD ditandai dengan SPL dingin di perairan barat Samudera Hindia dan hangat di perairan timur Samudera Hindia.

Suhu permukaan laut sangat berperan penting dalam mengendalikan iklim dan cuaca, serta dapat mempengaruhi pola 
angin, gerak arus laut, gelombang, metabolisme biota laut, dan pola penyebaran klorofil-a. Fenomena Indian Ocean Dipole terbagi dalam tiga fase, yakni fase netral fase positif, dan fase negatif. Fase netral IOD tidak memberikan pengaruh yang signifikan terhadap perubahan iklim dan nilai SPL mendekati normal (Bureau of Metereology Australia, 2019). Fase positif IOD ditunjukkan oleh nilai indeks yang berada lebih dari $+0,35$ sedangkan fase negatif dari fenomena ini ditunjukkan oleh nilai indeks yang kurang dari -0,35 (Tjasyono et al., 2008).

IOD memberikan pengaruh yang cukup signifikan terhadap distribusi suhu permukaan laut dan pola curah hujan di Sumatera Barat. Secara umum, jika terjadi IOD positif maka dampaknya terhadap curah hujan di Indonesia bagian barat akan berkurang, sebaliknya pada kejadian IOD negatif curah hujan di Indonesia akan cukup banyak (Wirjohamidjojo dan Swarinoto, 2010).

Untuk melihat pengaruh tersebut, diperlukan teknologi yang efektif dan efisien salah satunya menggunakan teknologi penginderaan jauh. Penelitian ini bertujuan untuk menganalisis pola distribusi SPL secara spasial serta menganalisis seberapa kuat pengaruh IOD terhadap distribusi anomali SPL selama fase IOD positif dan IOD negatif, dan untuk mengetahui pengaruh IOD terhadap intensitas curah hujan di Provinsi Sumatera Barat, serta memetakan distribusi SPL dan menganalisis sebaran SPL secara klimatologis di perairan Sumatera Barat selama 11 tahun.

Penelitian ini juga diharapkan dapat memberikan informasi tentang pengaruh fenomena IOD terhadap distribusi SPL dan intensitas curah hujan di Sumatera Barat, serta memberikan informasi baru bagi para peneliti sehingga dapat dijadikan referensi untuk penelitian selanjutnya.

\section{METODE PENELITIAN Waktu dan Tempat}

Pengambilan data lapangan serta pengamatan karakteristik dan kondisi perairan dilakukan pada bulan Januari 2020 bertempat di Perairan Teluk Mandeh, Nagari Carocok Anau, Kabupaten Pesisir Selatan, Provinsi Sumatera Barat (Gambar $1)$.

Pengolahan dan analisis data telah dilakukan pada bulan November 2019 Februari 2020, bertempat di Laboratorium Oseanografi Fisika, Jurusan Ilmu Kelautan, Fakultas Perikanan dan Kelautan, Universitas Riau.

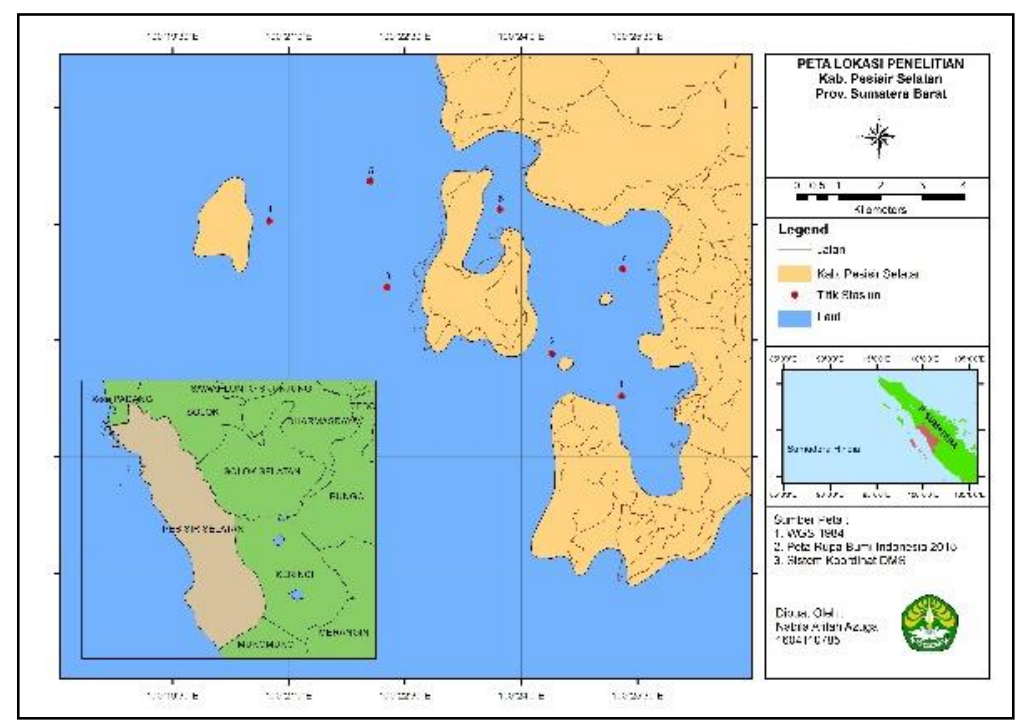

Gambar 1. Peta Lokasi Penelitian 


\section{Metode Penelitian}

Metode yang digunakan dalam penelitian ini adalah metode survey yaitu melakukan pengamatan karakteristik dan kondisi perairan serta pengambilan data secara langsung di lapangan. Pengolahan dan analisis data digunakan metode statistik dan deskriptif, yang berfungsi untuk menggambarkan pengaruh dari fenomena IOD terhadap distribusi suhu permukaan laut melalui hasil analisis dari uji statistika pada data-data yang telah diolah.

Data yang digunakan dalam penelitian ini adalah data primer meliputi data Buoys dan data hasil pengukuran di lapangan dan data sekunder yaitu data reanalisis SPL (OI) harian NOAA, data curah hujan BMKG, dan Dipole Mode Index (DMI).

\section{Prosedur Penelitian}

Untuk membuat peta distribusi dan anomali SPL di Perairan Sumatera Barat selama 11 tahun (tahun 2008-2018) digunakan data reanalisis SPL (OI) harian NOAA yang diunduh melalui website https://www.esrl.noaa.gov, dan untuk Dipole Mode Index (DMI) diunduh melalui website https://www.pmel.noaa.gov/.

Data reanalisis SPL (OI) harian NOAA yang telah diunduh kemudian akan dikonversi menggunakan software $C D O$ menjadi data bulanan, kemudian dikonversi menjadi data 11 tahun, dan dikonversi lagi menjadi data klimatologi. Untuk mengkonversi data tersebut, digunakan perhitungan secara statistik menurut Schulzweida (2019) dengan model matematis sebagai berikut:

Average

$$
o(t, x)=\operatorname{avg}\left\{i\left(t^{\prime}, x\right), t_{1}<t^{\prime} \leq t_{n}\right\}
$$

$$
\begin{array}{lll}
\text { Keterangan : } & \\
\mathrm{t} & = & \text { waktu } \\
\mathrm{X} & = & \text { ruang } \\
\mathrm{i} & = & \text { variabel (bulan) } \\
\mathrm{O} & = & \text { parameter (SPL) }
\end{array}
$$

Data klimatologi dan data SPL 11 tahun yang telah diolah, selanjutnya akan didapatkan peta distribusi anomali suhu permukaan laut setiap bulan (Januari Desember) selama 11 tahun yang berguna untuk melakukan analisis fenomena IOD di perairan Sumatera Barat. Untuk menghitung nilai anomali SPL digunakan perhitungan menurut (Eschenbach, 2013) sebagai berikut :

\section{Anomali SPL = Nilai SPL tahun yang dihitung - Nilai SPL klimatologi}

Dari pengolahan dan analisis data tersebut akan dihasilkan output yaitu peta distribusi dan anomali SPL selama 11 tahun yang kemudian dibahas dan dianalisis secara deskriptif dengan merujuk kepada buku, jurnal, dan hasil penelitian sebelumnya terkait fenomena IOD dan suhu permukaan laut.

\section{HASIL DAN PEMBAHASAN Kondisi Umum}

Daerah kajian dalam penelitian ini adalah wilayah perairan Sumatera Barat, berada pada posisi 0 31'25,69 LU $1^{\circ} 03 ' 53,23$ " LS dan 95 $011^{\prime} 07,71^{\prime \prime}$ $101^{\circ} 20^{\prime} 09,76^{\prime \prime}$ BT (Gambar 2). 


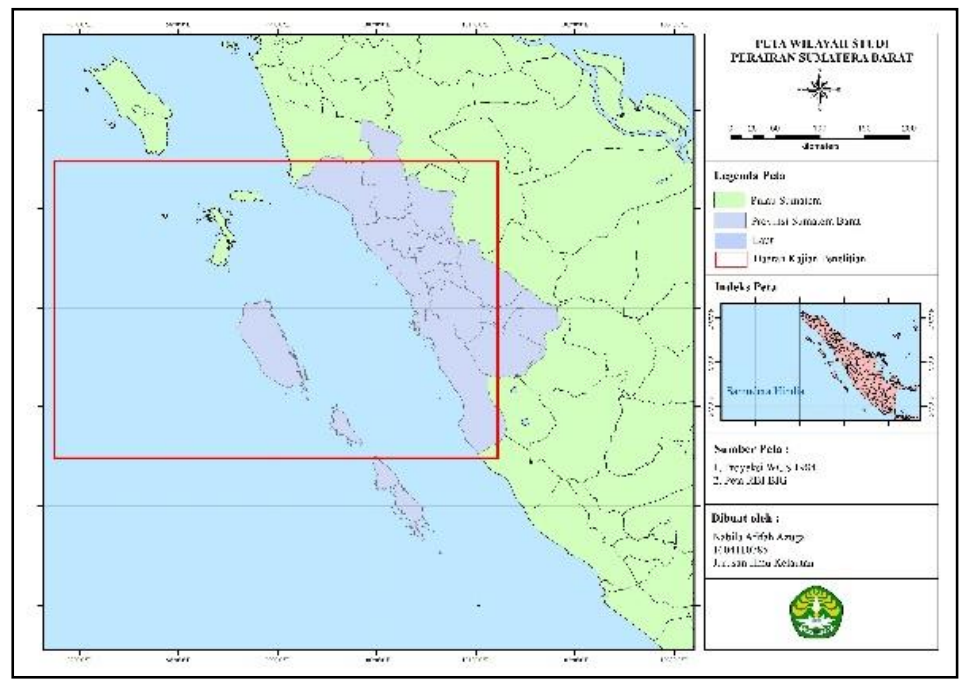

Gambar 2. Peta Daerah Kajian

\section{Validasi Data}

Uji validasi data dilakukan untuk mengetahui tingkat akurasi antara nilai SPL dari data reanalisis (OI) harian NOAA dengan nilai SPL dari data Buoys. Tingkat akurasi tersebut menjadi tolak ukur apakah data data hasil pengolahan dapat mewakili nilai SPL sesungguhnya di perairan atau tidak. Selain itu, validasi data juga digunakan untuk mengetahui kedekatan antara nilai dari data hasil pengolahan dan nilai dari data Buoys.

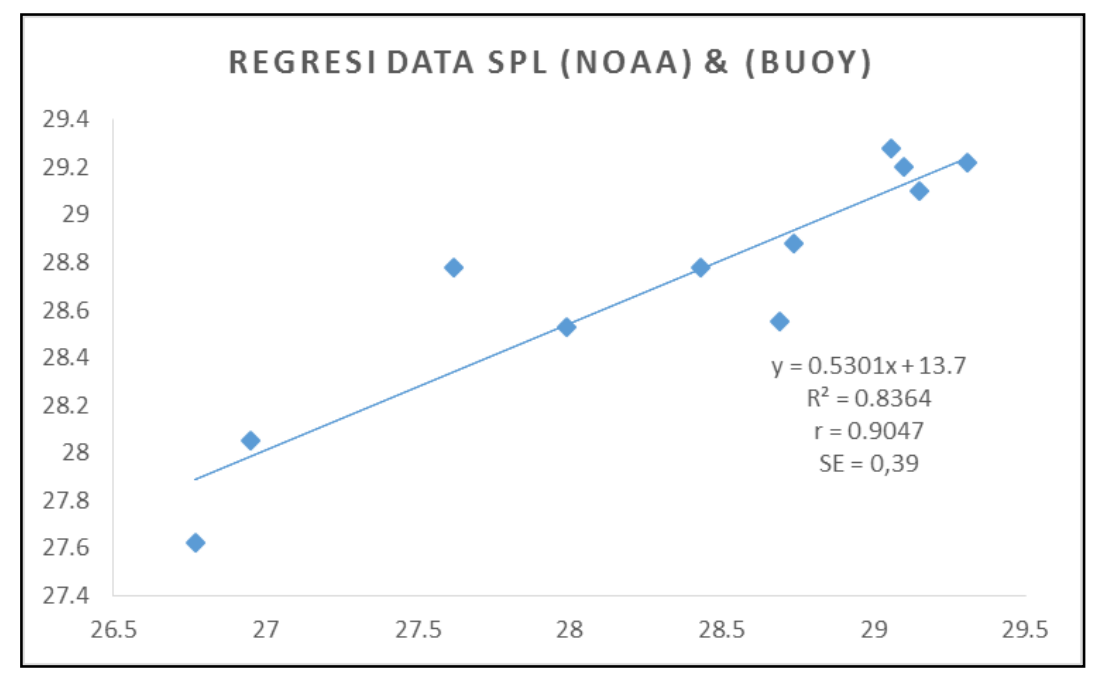

Gambar 3. Grafik Hasil Uji Regresi Data Reanalisis SPL (OI) Harian dengan Data Buoys

Dari hasil tersebut maka dapat disimpulkan bahwa nilai SPL dari data reanalisis SPL (OI) harian NOAA dapat digunakan dalam penelitian ini karena tingkat akurasi data hasil pengolahan cukup tinggi sehingga mampu mewakili nilai SPL sesungguhnya dari wilayah perairan yang diteliti.

\section{Fenomena IOD di Perairan Sumatera Barat}

Fenomena Indian Ocean Dipole digambarkan melalui sebuah indeks yaitu Dipole Mode Index (DMI). DMI selama 11 tahun (2008-2018) ditampilkan pada Gambar 4. 


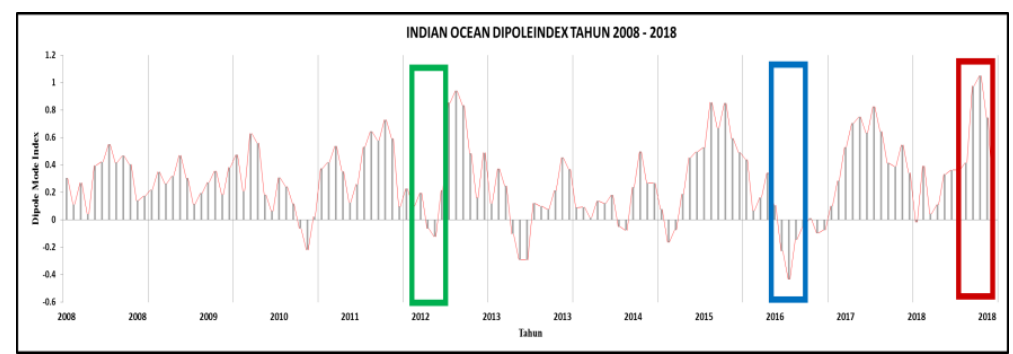

Gambar 4. Grafik Dipole Mode Index (DMI) Tahun 2008-2018

Grafik DMI menunjukkan bahwa fenomena IOD positif puncaknya terjadi pada bulan Oktober tahun 2018 (nilai indeks 1,05) dan IOD fase negatif puncaknya terjadi pada bulan Juli tahun 2016 (nilai indeks $-0,435$ ).

\section{Analisis Pengaruh Fenomena IOD Terhadap Distribusi dan Anomali SPL \\ Fenomena Indian Ocean Dipole} sangat berpengaruh terhadap pola sebaran

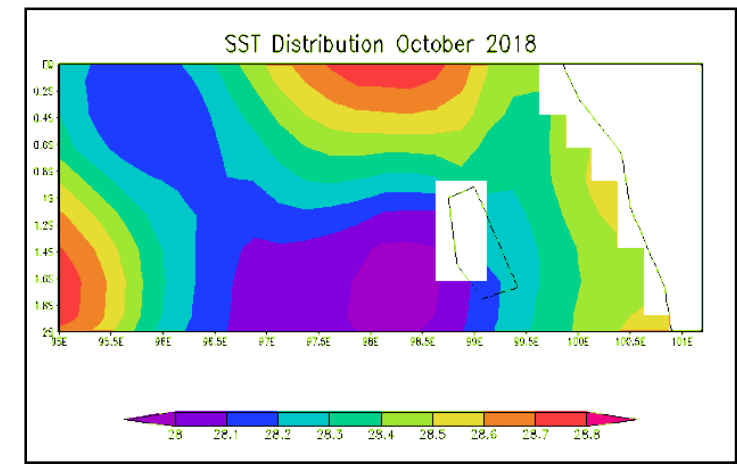

a
SPL di perairan Sumatera Barat. Pada tahun-tahun yang menunjukkan terjadinya fenomena IOD fase positif (tahun 2018) atau fase IOD negatif (tahun 2016), suhu permukaan laut di perairan Sumatera Barat memiliki pola distribusi dan nilai anomali yang berbeda. Peta distribusi SPL pada fase positif dan fase negatif IOD dapat dilihat pada Gambar 5.

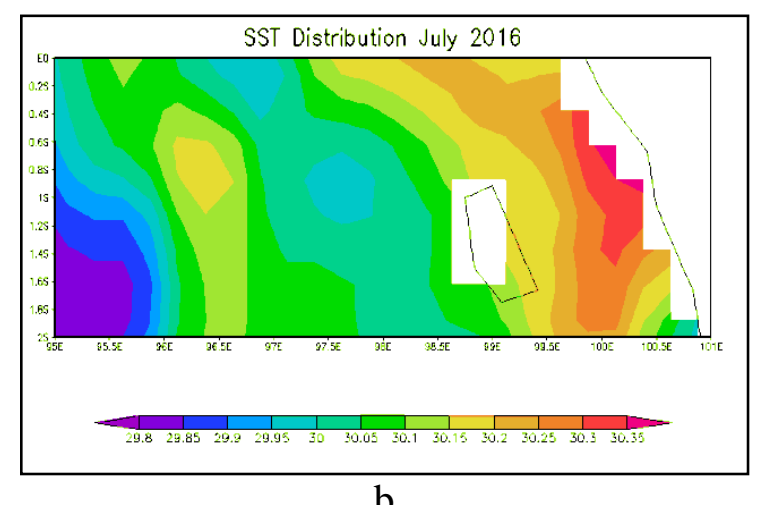

b

Gambar 5. Peta Distribusi SPL: (a) Fase IOD Positif; (b) Fase IOD Negatif

Hasil analisis peta distribusi SPL menunjukkan bahwa pada fase IOD positif (Gambar 4a) dengan nilai rata-rata SPL yakni $(28 ; 28,1 ; 28,2 ; 28,3 ; 28,4 ; 28,5$; 28,$6 ; 28,7 ; 28,8{ }^{\circ} \mathrm{C}$ ) lebih rendah daripada nilai rata-rata SPL $(29,8 ; 29,85 ; 29,9$; 29,$95 ; 30 ; 30,05 ; 30,1 ; 30,15 ; 30,2 ; 30,25$; 30,$\left.3 ; 30,35^{\circ} \mathrm{C}\right)$ saat terjadinya IOD negatif (Gambar 5a).

Pola distribusi SPL pada fase IOD positif (Gambar 4a) cenderung lebih tinggi pada bagian dekat perairan Samudera Hindia dengan nilai suhu berkisar antara $28,3-28,8{ }^{\circ} \mathrm{C}$ dibandingkan dengan perairan Sumatera Barat dengan nilai suhu berada dalam kisaran $28-28,5{ }^{\circ} \mathrm{C}$. Pada fase IOD negatif Gambar 4 (b), memperlihatkan bahwa distribusi SPL cenderung lebih tinggi pada perairan Sumatera Barat dengan nilai suhu berkisar antara 29,8 - 30,05 ${ }^{\circ} \mathrm{C}$ dibandingkan dengan nilai SPL pada perairan dekat Samudera Hindia yaitu berkisar antara $30,05-30,35{ }^{\circ} \mathrm{C}$.

Fase IOD positif ditunjukkan dengan nilai distribusi SPL yang lebih dingin dari pada biasanya. Sebaliknya, pada fase IOD negatif, menunjukkan bahwa SPL di sekitar 
barat Sumatera khususnya perairan Sumatera Barat lebih hangat daripada biasanya.

Iskandar (2014) dalam penelitiannya menjelaskan bahwa fase IOD positif ditunjukkan oleh nilai suhu rendah yang menyimpang dari keadaan normalnya pada garis ekuator bagian tenggara Samudera Hindia (mencakup perairan Sumatera Barat) dan nilai suhu tinggi yang menyimpang dari keadaan normalnya pada pusat hingga ke garis ekuator bagian barat Samudera Hindia.

Hal yang sama juga dijelaskan oleh Khaldun et al. (2018) dalam penelitiannya, yaitu saat fase IOD positif distribusi nilai

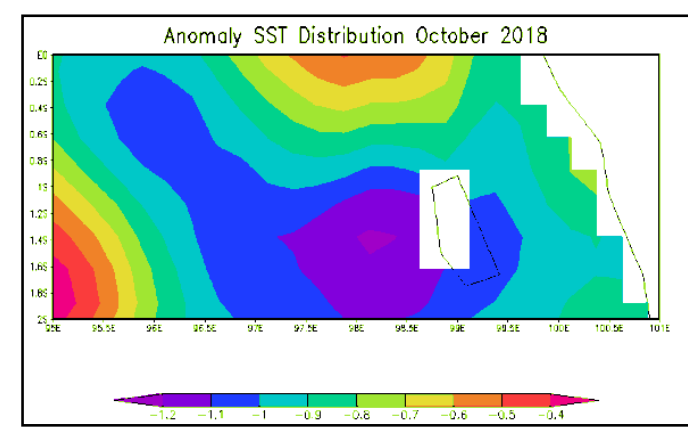

a

SPL di Pulau Sumatera lebih rendah berkisar antara $27,63-27,71{ }^{\circ} \mathrm{C}$, namun pada fase IOD negatif distribusi nilai SPL meningkat yaitu berkisar antara 27,75 $27,85^{\circ} \mathrm{C}$.

Anomali SPL merupakan sebuah penyimpangan yang mengakibatkan terjadinya pergeseran nilai SPL. Pergeseran tersebut salah satunya terjadi karena diakibatkan oleh adanya fenomena global seperti Indian Ocean Dipole (IOD) yang menyebabkan kenaikan atau penurunan suhu daripada keadaan normalnya. Peta distribusi anomali SPL fase positif dan negatif IOD ditunjukkan oleh Gambar 6.

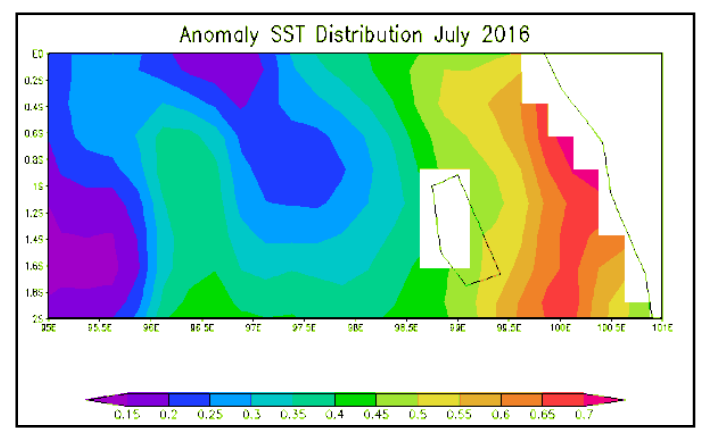

b

Gambar 6. Peta Distribusi Anomali SPL(a) Fase Positif; (b) Fase Negatif

Nilai anomali SPL pada fase IOD positif (Gambar 5a) menunjukkan nilai anomali yaitu $(-1,2 ;-1,1 ;-1 ;-0,9 ;-0,8$; $0,7 ;-0,6 ;-0,5 ;-0,4)$, sedangkan nilai anomali SPL pada fase IOD negatif yaitu $(0,15 ; 0,2 ; 0,25 ; 0,3 ; 0,35 ; 0,4 ; 0,45 ; 0,5$; $0,55 ; 0,6 ; 0,65 ; 0,7)$.

Distribusi anomali SPL fase IOD positif menunjukkan nilai negatif, yang berarti pada fase ini SPL mengalami pergeseran dengan terjadinya penurunan suhu pada perairan Sumatera Barat. Namun, kondisi sebaliknya terjadi selama fase IOD negatif dimana nilai anomali bersifat positif yang berarti adanya pergeseran nilai SPL dengan terjadinya peningkatan nilai SPL pada perairan Sumatera Barat.
Chambers et al., (1999) dan Webster et al., (1999) menjelaskan bahwa pada saat terjadinya IOD positif, SPL cenderung lebih dingin dari pada biasanya dan pada saat yang bersamaan terjadi penurunan curah hujan di bagian barat Sumatera yang menyebabkan kekeringan, sedangkan pada fase IOD negatif, menurut lizuka et al., (2000) menyatakan bahwa, suhu permukaan laut lebih hangat dari pada biasanya dan pada saat bersamaan terjadi pembentukan konveksi yang mengakibatkan peningkatan terhadap curah hujan di bagian barat Sumatera.

Iskandar (2014) juga menjelaskan bahwa adanya anomali SPL saat fase IOD positif dan negatif disebabkan oleh pola sirkulasi angin di Samudera Hindia yang 
dipengaruhi oleh musim yang disebut dengan angin muson.

\section{Pengaruh Fenomena IOD Terhadap Intensitas Curah Hujan di Provinsi Sumatera Barat}

Wilayah perairan Sumatera Barat yang berhadapan langsung dengan Samudera Hindia, menyebabkan perairan ini terkena dampak dari fenomena IOD dengan cukup signifikan sehingga sangat mempengaruhi pola distrubusi suhu serta menyebabkan perbedaan intensitas curah hujan di Provinsi Sumatera Barat. Data curah hujan pada fase IOD positif dan negatif yaitu disajikan pada Tabel 1 .

Tabel 1. Data Curah Hujan Kejadian IOD

\begin{tabular}{|c|c|c|c|}
\hline Nama Stasiun & IOD & Periode & $\begin{array}{c}\text { Rata-rata Curah } \\
\text { Hujan (mm) }\end{array}$ \\
\hline \multirow{2}{*}{$\begin{array}{c}\text { Data BMKG } \\
\text { Sumatera Barat }\end{array}$} & Positif & $\begin{array}{c}01 \text { Oktober } 2018 \mathrm{~s} / \mathrm{d} \\
31 \text { Oktober } 2018\end{array}$ & 157 \\
\hline & Negatif & $\begin{array}{l}\text { 01 Juli } 2016 \\
\text { s/d } \\
\text { 31 Juli } 2016\end{array}$ & 525 \\
\hline
\end{tabular}

(Sumber : Badan Metereologi, Klimatologi, dan Geofisika, 2020)

Rata-rata curah hujan $(\mathrm{CH})$ selama periode IOD positif adalah $157 \mathrm{~mm}$ sedangkan rata-rata curah hujan selama periode IOD negatif adalah $525 \mathrm{~mm}$. Berdasarkan nilai tersebut, dapat dijelaskan bahwa selama fase IOD positif di daerah Sumatera Barat telah terjadi penurunan intensitas curah hujan karena pembentukan massa awan terjadi pada bagian barat Samudera Hindia, sedangkan pada fase IOD negatif intensitas $\mathrm{CH}$ cenderung lebih tinggi, hal ini diduga disebabkan karena pembentukan masa awan terjadi pada bagian timur Samudera Hindia yang mencakup Provinsi Sumatera Barat sehingga menyebabkan tingginya $\mathrm{CH}$ pada periode ini.

Hal yang sama dijelaskan oleh penelitian yang dilakukan Hermawan (2010), bahwa pada kejadian IOD positif tahun 1980 hingga 1999 pada bulan September, Oktober, dan November (SON) mengalami penurunan curah hujan dari pada intensitas normalnya. Hal ini ditunjukkan oleh korelasi yang cukup signifikan, yaitu $r<-1$ dan mengindikasikan bahwa adanya penurunan curah hujan di Samudera Hindia tropis bagian timur.

Pada kejadian IOD negatif, pembentukan massa awan terjadi pada bagian timur Samudera Hindia, yang mencakup wilayah barat Sumatera (salah satunya daerah Sumatera Barat) sehingga intensitas curah hujan lebih tinggi (Iskandar, 2014).

Adanya fenomena IOD menurut (Gusmira, 2005) mengakibatkan terjadinya percepatan datangnya musim hujan pada fase IOD negatif dan memperpanjang musim kemarau pada fase IOD positif.

Fenomena IOD positif yang terjadi pada bulan Oktober merupakan fase dimana matahari berada pada belahan bumi selatan (BBS) sehingga terbentuklah angin monsun baratan (musim barat), pada musim ini wilayah Indonesia cenderung mengalami musim hujan (Syafik et al., 2013; Yananto dan Sibarani, 2016). Namun sebaliknya, adanya fenomena IOD diduga menyebabkan intensitas curah hujan menurun.

Begitu juga pada fase IOD negatif yang terjadi pada bulan Juli dan merupakan periode dimana matahari berada pada bumi belahan utara (BBU) sehingga terbentuklah angin monsun timur (musim timur) sehingga mengakibatkan terjadinya musim kemarau (kering) di Indonesia (Syafik et al., 2013; Yananto dan Sibarani, 2016). Tetapi, adanya fenomena IOD, diduga menyebabkan terjadi pergeseran musim dimana pada waktu tersebut daerah Sumatera Barat mengalami peningkatan intensitas hujan. 
Distribusi SPL Berdasarkan Analisis Klimatologi 11 Tahun (Tahun 20082018) di Perairan Sumatera Barat

Nilai SPL yang diperoleh dari hasil analisis klimatologis 11 tahun (2008-2018)

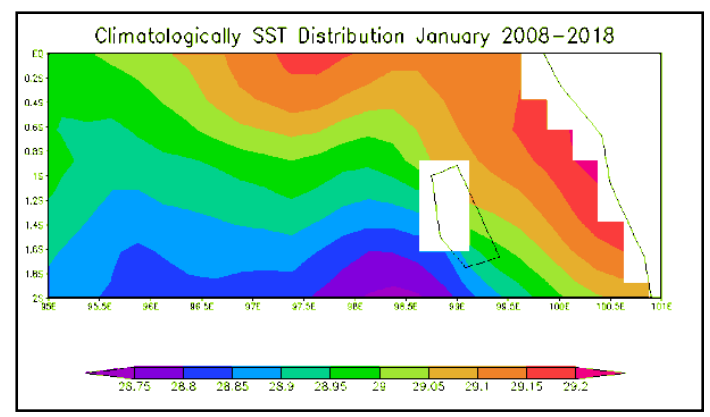

a

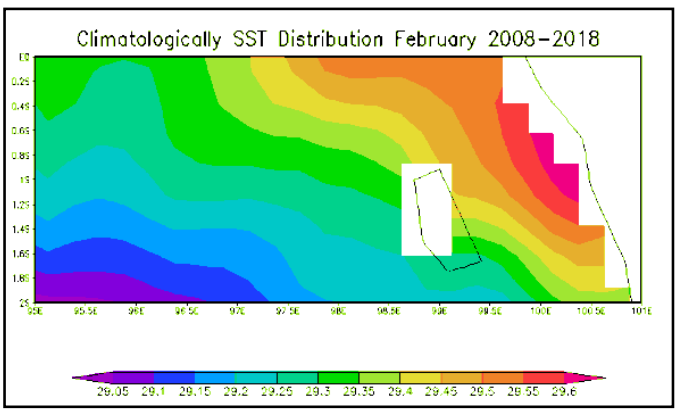

c

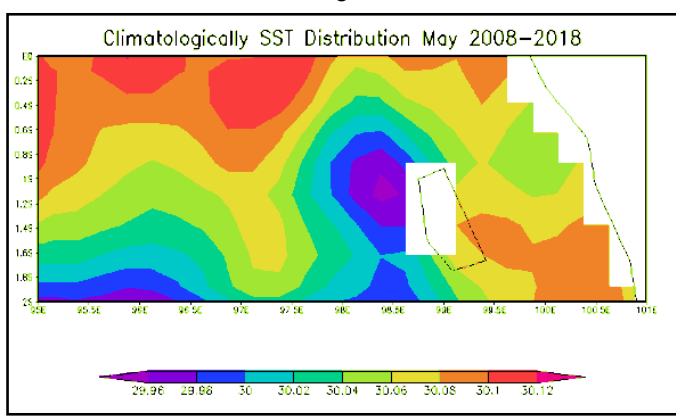

$\mathrm{e}$

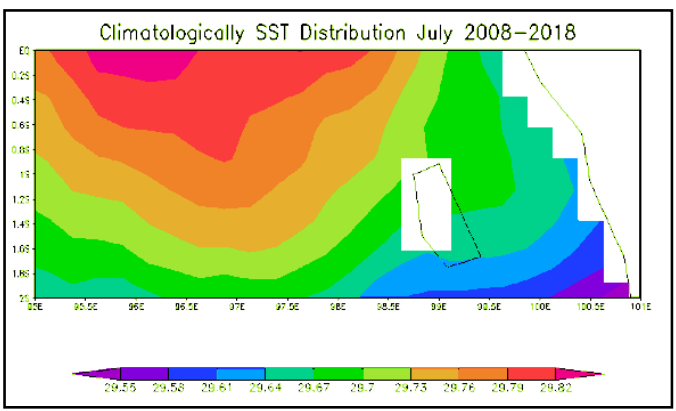

g digunakan untuk melihat distribusi dan mengetahui nilai anomali SPL di perairan Sumatera Barat. Distribusi SPL secara klimatologis ditunjukkan oleh Gambar 7.

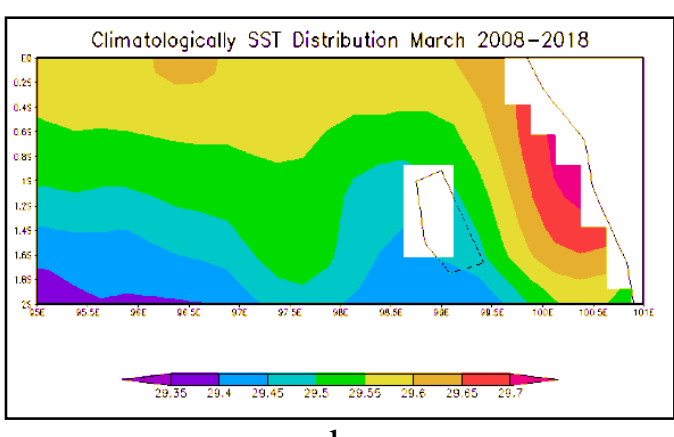

b

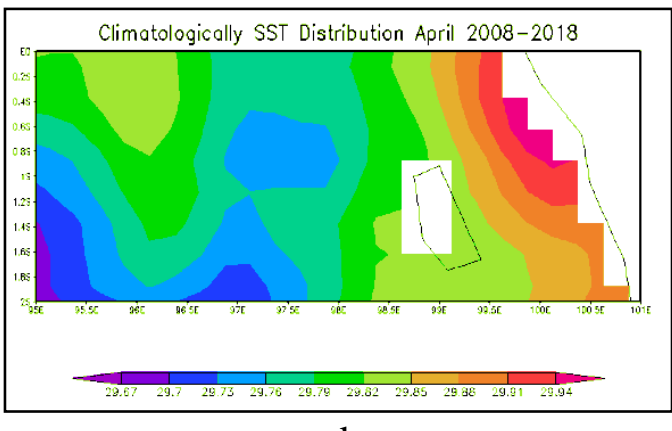

d

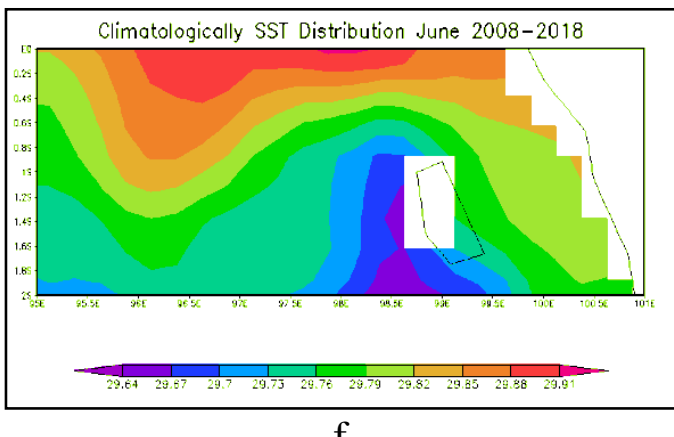

$\mathrm{f}$

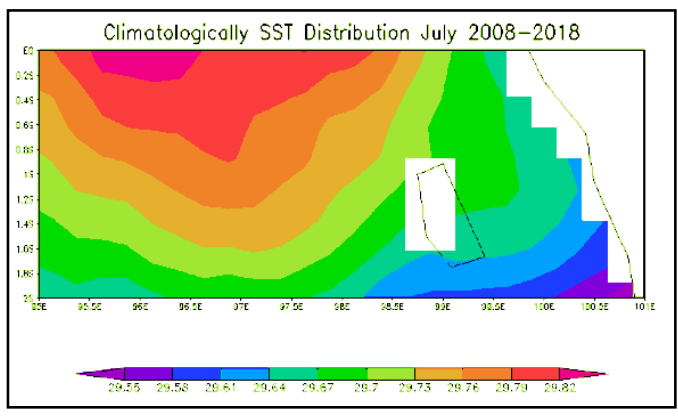

$\mathrm{h}$ 

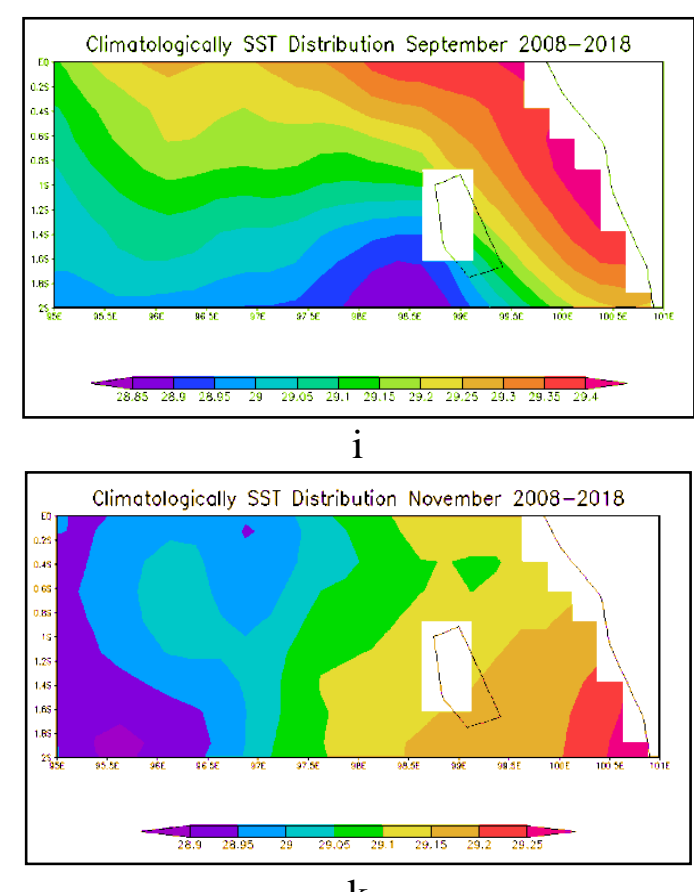

$\mathrm{k}$

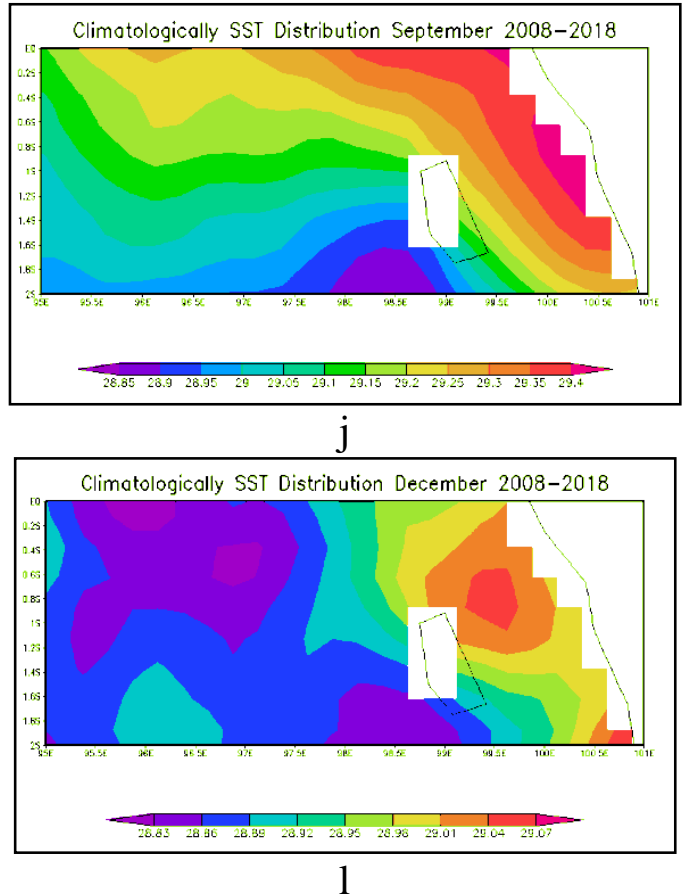

Gambar 7. Peta Sebaran Suhu Permukaan Laut Secara Klimatologis Selama 11 Tahun: (a) Januari; (b) Februari; (c) Maret; (d) April; (e) Mei; (f) Juni; (g) Juli; (h) Agustus; (i) September; (j) Oktober; (k) November; (1) Desember

Berdasarkan hasil analisis klimatologi menunjukkan bahwa nilai SPL pada daerah yang dianalisis berkisar antara $28,75^{\circ} \mathrm{C}-$ $30,12{ }^{\circ} \mathrm{C}$. Rata-rata nilai SPL pada bulan Januari cenderung lebih rendah daripada bulan lainnya dengan nilai yaitu $(28,75$; 28,$8 ; 28,85 ; 28,9 ; 28,95 ; 29 ; 29,05 ; 29,1$; 29,$15 ; 29,2$ ), pada periode ini merupakan terjadinya musim barat dimana posisi matahari berada pada bumi bagian selatan (BBS) sehingga mengakibatkan belahan bumi Selatan khususnya Australia lebih banyak memperoleh pemanasan matahari daripada benua Asia maka dari itu suhu di Australia tinggi, sedangkan suhu di benua Asia rendah (Wyrtki dalam Yananto dan Sibarani 2016; Syafik et al., 2013).

Rata-rata nilai SPL tertinggi ditunjukkan pada bulan Mei dengan nilai yaitu $(29,96 ; 29,98 ; 30 ; 30,02 ; 30,04$; 30,$06 ; 30,08 ; 30,1 ; 30,12$ ), pada bulan ini menunjukkan periode dimana terjadinya musim timur (monsun timur) dimana posisi matahari berada pada bumi belahan utara (BBU), di belahan bumi Utara khususnya
Benua Asia suhunya menjadi tinggi dan tekanan udaranya rendah (minimum) (Syafik et al., 2013; Wyrtki dalam Yananto dan Sibarani) bersamaan pula dengan terjadinya musim peralihan I dimana pada musim ini posisi matahari berada di ekuator sehingga mengakibatkan peningkatan suhu permukaan laut pada perairan Sumatera Barat (Rahayu et al., 2018).

Pola sebaran SPL secara klimatologis di perairan Sumatera Barat mendekati daerah pantai memiliki suhu lebih tinggi dibandingkan nilai suhu permukaan laut pada perairan dekat Samudera Hindia. Tingginya nilai SPL pada perairan Sumatera Barat dekat dengan daerah pantai diduga diakibatkan oleh masih tingginya pengaruh dari daratan sehingga nilai suhu cendering meningkat, sedangkan pada perairan Samudera Hindia nilai SPL cenderung lebih rendah karena kurangnya pengaruh daratan terhadap perairan tersebut (Wahyuningrum et al., 2011). 


\section{KESIMPULAN DAN SARAN}

Pola distribusi SPL yang dianalisis secara spasial saat terjadinya fenomena IOD positif menunjukkan bahwa nilai ratarata SPL cenderung lebih rendah daripada nilai rata-rata SPL saat terjadinya fenomena IOD negatif.

Nilai anomali suhu pada fase IOD positif ditunjukkan oleh indeks nilai bersifat negatif yang mengartikan bahwa selama periode ini terjadi pergeseran nilai SPL yang ditandai dengan penurunan suhu. Hal sebaliknya terjadi pada fenomena IOD fase negatif, indeks nilai anomali SPL pada fase ini bersifat positif yang menandakan bahwa pergeseran SPL ditandai dengan terjadinya peningkatan suhu pada fase IOD negatif.

Selama fase IOD positif, nilai ratarata $\mathrm{CH}$ di Sumatera Barat lebih rendah daripada nilai rata-rata $\mathrm{CH}$ pada fase negatif. Hal ini disebabkan oleh adanya anomali suhu permukaan laut pada perairan sehingga menyebabkan pergeseran waktu terjadinya hujan. Pada fase positif IOD terjadi penurunan intensitas $\mathrm{CH}$ di Sumatera Barat, sedangkan pada fase IOD negatif terjadi peningkatan intensitas $\mathrm{CH}$ di Sumatera Barat.

Pola distribusi SPL selama 11 tahun (2008-2018) yang telah dianalisis secara klimatologis menunjukkan bahwa rata-rata nilai SPL terendah terjadi selama bulan Januari, sedangkan rata-rata nilai SPL tertinggi terjadi pada bulan Mei.

Untuk penelitian selanjutnya, perlu dilakukan kajian lebih luas tentang parameter iklim dan kaitannya dengan kejadian Indian Ocean Dipole dengan lebih detil dan memahami penggunaan software untuk pengolahan data iklim sehingga akan mempermudah dalam melakukan penelitian dan hasil yang diperoleh akan lebih akurat

\section{DAFTAR PUSTAKA}

1. Bureau of Meteorology Australia. (2019). Climate Monitoring Graphs. [Online] Diakses pada: 20 September 2019, pukul 22.34 WIB. Tersedia: http://www.bom.gov.au/climate/enso/indices/iod-area-map.gif.

2. Chambers, D.P., B.D. Tapley, and R.H. Stewart, (1999): Anomalous warming in the Indian Ocean coincident with El Niño. J. Geophys. Res., 104, 3035-3047.

3. Eschenbach, W. (2013). Monthly Averages, Anomalies, and Uncertainties. [Online]. Diakses pada: 23 Desember 2019, pukul 19.15 WIB. Tersedia: https://wattsupwiththat.com/2013/08/17/monthly-averages-anomalies-and-uncertainties/.

4. Gusmira, E. (2005). Pengaruh Dipole Mode Terhadap Angin Zonal dan Curah Hujan di Sumatera Barat. Thesis. Fakultas Teknik dan Ilmu Kebumian. Institut Teknologi Bandung. Bandung.

5. Hermawan, E. (2010). Pengelompokkan Pola Curah Hujan Yang Terjadi di Beberapa Kawasan P. Sumatera Berbasis Hasil Analisis Teknik Spektral. Jurnal Meteorologi dan Geofisika. 11 (2). 75-85.

6. Iizuka, S.,T. Matsuura and T. Yamagata. (2000). The Indian Ocean SST Dipole Simulated In a Coupled General Circulation Model. Geophysical Research Lett. 27: 3369-3372.

7. Iskandar, M.R. (2014). Mengenal Indian Ocean Dipole (IOD) dan Dampaknya pada Perubahan Iklim. 39 (2). 13-21.

8. Kailaku, T.E. (2009). Pengaruh ENSO (El Nino-Southern Oscillation) dan IOD (Indian Ocean Dipole) terhadap Dinamika Waktu Tanam Padi di Wilayah Tipe Hujan Equatorial 
dan Monsunal (Studi Kasus Kabupaten Pesisir Selatan, Sumatera Barat dan Kabupaten Karawang, Jawa Barat). Skripsi. Fakultas Matematika dan Ilmu Pengetahuan Alam. Institut Pertanian Bogor. Bogor.

9. Rahayu, N.D., B. Sasmito., dan N. Bashit. (2018). Analisis Pengaruh Fenomena Indian Ocean Dipole (IOD) Terhadap Curah Hujan di Pulau Jawa. Jurnal Geodesi Undip. 7 (1). 57-67.

10. Sahu N, S.K. Behera, Y. Yamashiki, K. Takara, and T. Yamagata . (2012). IOD and ENSO impacts on the extreme stream-flows of Citarum River in Indonesia. Climate Dynamics. 39. 1673-1680.

11. Schulzweida, U. (2019). CDO User Guide. MPI for Meteorology. 222.

12. Syafik, A., Kunarso., dan Hariadi. (2013). Pengaruh Sebaran Dan Gesekan Angin Terhadap Sebaran Suhu Permukaan Laut di Samudera Hindia (Wilayah Pengelolaan Perikanan Republik Indonesia 573) Jurnal Oseanografi. 3 (3). 318-328.

13. Websters, J.P., Moore, A.M., Loschnigg and Leben, R.R. 1999. Coupled

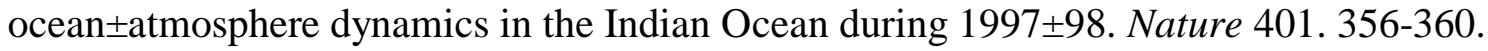

14. Tjasyono, B., Atika, L., Ina, J., Ruminta, R., dan Sri, W. B. H. (2008). Dampak Variasi Temperatur Samudera Pasifik dan Hindia Ekuatorial Terhadap Curah Hujan di Indonesia. Jurnal Sains Dirgantara. 5 (2). 83-95.

15. Wahyuningrum, P.I., D. Simbolon., dan R. Rizkawati. (2011). Pengaruh Suhu Permukaan Laut Terhadap Hasil Tangkapan Ikan Tenggiri di Perairan Indramayu, Jawa Barat. Skripsi. Departemen Pemanfaatan Sumber Daya Perikanan, Fakultas Perikanan dan Ilmu Kelautan, Institut Pertanian Bogor. Bogor.

16. Wirjohamidjojo, S. dan Y. Swarinoto. (2010). Iklim Kawasan Indonesia (Dari Aspek Dinamik - Sinoptik). Badan Meteorologi Klimatologi dan Geofisika : Jakarta.

17. Yananto, A., dan R.M. Sibarani. (2016). Analisis Kejadian El Nino dan Pengaruhnya Terhadap Intensitas Curah Hujan di Wilayah Jabodetabek (Studi Kasus : Periode Puncak Musim Hujan Tahun 2015/2016). Jurnal Sains \& Teknologi Modifikasi Cuaca. 17 (2). 65-73. 